\title{
報文
}

\section{吸着指示藥による滴定・(第三報) 沃化物の銀滴定に用ひ得る數種の指示藥について}

(昭和八年九月计日受領 昭和八年十一月而日印刷)

太秦, 康光三宅泰政

著者等は前報告1)に於てロダン酸盆の銀滴定に用ひ得る吸着指示藥として新に十一種の色素を舉げ た. 而してそれらは何れる通常中和滴定に指示紧として用ひられてるるものであつね.この十一種 の色素中には當然ハロゲンーイオンの銀滴定にも使用し得るすのあるべしと穆想されたので, 銀の各 八ロゲン化物に就て之等色素の吸着巴を檢したる結果，次に示す六種の昏装が著しい色の變化を示

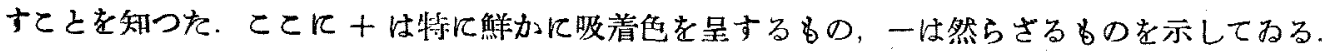

第

表

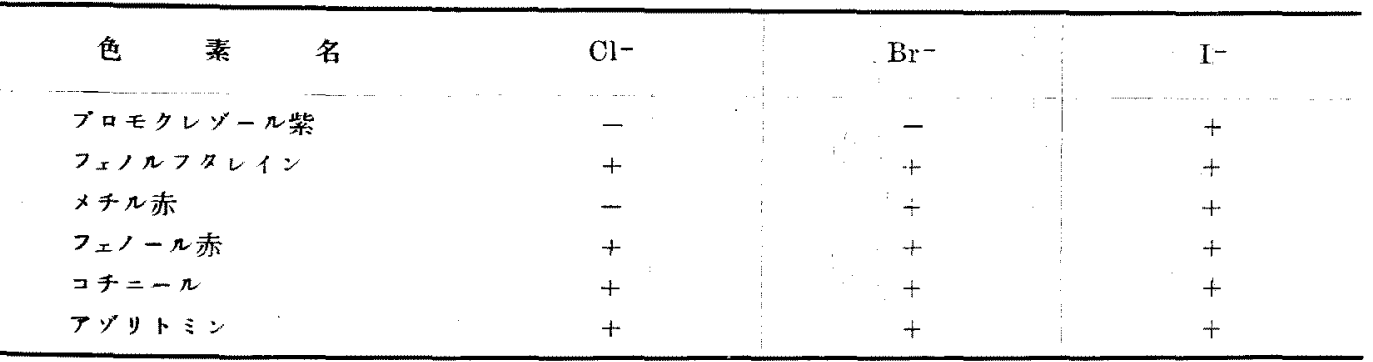

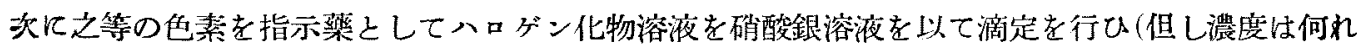

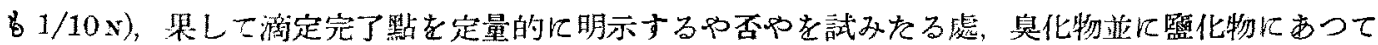

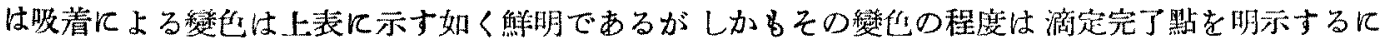
は猶不充分であつた。そに反し沃化物の場合には滴定完了點に於ける變色は定量的に頗る鮮明に行 はれ滿足すべ結果を示したのである，その詳細なる䁈驗結果は實驗の部に示す如くであるが，之 によつて之等の出素は從來のフルオレスセイン族のbのと同㥞に沃化物銀滴定に於ける良好交る指 示藥として使用し得ることが明になつたのである。

\section{實 驗 の 部}

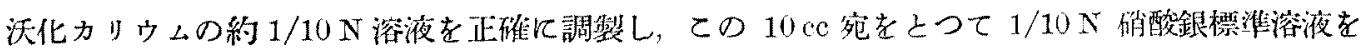

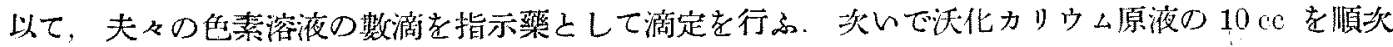

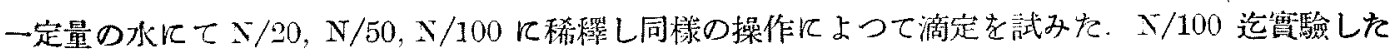

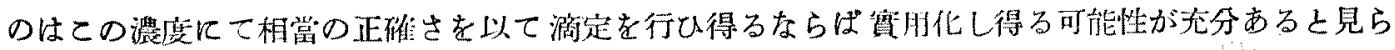

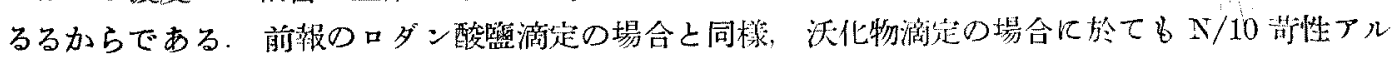

1) 柆誌, 54 (1933), 624 . 
カリ溶液の一滴乃至數滴を加へて微アルカリ性となしおくカが結果がよい．但しアゾリトミンの場 合はアルカリ添加せ市して行ふを可とする.

沃化カリウムの瀶度 $\mathrm{N} / 10$ 乃至 $\mathrm{N} / 20$ に於ては滴定完了點にて沃化銀の㠜集甚しく，ために液は 瞬時にして透明となる、然しこの所謂透明點 (Klarpunkt) に達すると同時に吸着色現出し, 從て沈 澱の凝集は反應完了點の認識を助けてそするが妨げるやうなことは殆どない，ただアデリトミンに あつては完了點に於りる沃化銀ジルの凝集は他の色素を用ひた時程著しくない. 之は 主として他素 イオンの吸着能の差によるものと思はれ，事實アジットミンは變色の銳敏度も他のるのに比し可成 り劣つてみる. 次に個ふの實驗結果を揭げる.

1. ブロモクレジール紫

少量のアルコールを含む飽和水溶液を製し之を指示藥として N/100 迄滴定し得た．この際變や仕 堇より綠に銳敏蘚明に行はれる。

第云表

\begin{tabular}{|c|c|c|c|}
\hline KI 溶液の濃度 (N) & $\begin{array}{c}\text { 要したる } \mathrm{N} / 10 \mathrm{AgNO} \text { 溶液 } \\
(\mathrm{cc})\end{array}$ & 指示樂敵數 & $\mathrm{N} / 10 \mathrm{KOH}$ 溶液滴数 \\
\hline $1 / 10 *$ & $\left.\begin{array}{l}10.31 \\
10.31 \\
10.30\end{array}\right\} 10.31$ & \}$^{5}$ & 2 \\
\hline $1 / 20$ & $\left.\begin{array}{l}10.31 \\
10.29 \\
10.30\end{array}\right\} 10.30$ & 3 & 4 \\
\hline $1 / 50$ & $\left.\begin{array}{l}10.30 \\
10.32 \\
10.33\end{array}\right\} 10.32$ & 5 & 6 \\
\hline $1 / 100$ & $\left.\begin{array}{l}10.33 \\
10.30 \\
10.32\end{array}\right\} 10.32$ & 10 & $\left\{\begin{array}{r}7 \\
10\end{array}\right.$ \\
\hline
\end{tabular}

* KI 原液濃度： $0.1031 \mathrm{~N}$

2. フェノルフタレイン

繸色は桃色から紫と行はれ N/100 迄滴定可能でする。指示葲は $1 \%$ のものを朋ふ.

\begin{tabular}{|c|c|c|c|c|}
\hline $\mathrm{KI}$ 溶液の滇度 $(\mathrm{N})$ & $\begin{array}{r}\text { 要したる } \mathrm{N} / 10 \\
\text { (ce }\end{array}$ & $\mathrm{AgNO}_{3}$ 溶液 & 指示藥滴 数 & $\mathrm{N} / 10 \mathrm{KOH}$ 溶液滴數 \\
\hline $1 / 10 *$ & $\left.\begin{array}{r}9.99 \\
10.01 \\
10.00 \\
10.00\end{array}\right\}$ & 10.00 & 2 & 2 \\
\hline $1 / 20$ & $\left.\begin{array}{r}10.01 \\
10.00 \\
9.99\end{array}\right\}$ & 10.00 & 2 & \} $\begin{array}{l}2 \\
3\end{array}$ \\
\hline $1 / 50$ & $\left.\begin{array}{r}9.99 \\
9.97 \\
10.01\end{array}\right\}$ & 9.99 & 5 & \} $\begin{array}{l}5 \\
7\end{array}$ \\
\hline $1 / 100$ & $\left.\begin{array}{l}10.01 \\
10.02 \\
10.04\end{array}\right\}$ & 10.02 & 10 & $\left\{\begin{array}{l}12 \\
15\end{array}\right.$ \\
\hline
\end{tabular}

* $\mathrm{KI}$ 原旅濃度： $0.0999 \mathrm{~N}$ 
3. メチル亦

フルコール鴒和溶液として用ひ N/100 迄相當の正碓さを以て滴定し得. 變凹は黄より橙赤にかな り鉸敏飞行はる.

\begin{tabular}{|c|c|c|c|c|}
\hline & 第 & 四 & 表 & \\
\hline KI 楁液の濃度 $(\mathrm{N})$ & $\begin{array}{r}\text { 要したる } \mathrm{N} / 10 \\
\text { (cc) }\end{array}$ & $\mathrm{AgNO}_{3}$ 溶液 & 指示藥䰙 數 & $\mathrm{N} / 10 \mathrm{KOH}$ 溶液敵数 \\
\hline $1 / 10 *$ & $\left.\begin{array}{l}9.99 \\
9.99 \\
9.99\end{array}\right\}$ & 9.99 & \}$_{15}^{10}$ & 1 \\
\hline $1 / 20$ & $\left.\begin{array}{r}10.00 \\
9.98 \\
9.99\end{array}\right\}$ & 9.99 & $\begin{array}{r}20 \\
10\end{array}$ & \}$_{1}^{2}$ \\
\hline $1 / 50$ & $\left.\begin{array}{l}9.97 \\
9.98 \\
9.99\end{array}\right\}$ & 9.98 & $\begin{array}{r}30 \\
25\end{array}$ & $\tilde{5}$ \\
\hline $1 / 100$ & $\left.\begin{array}{l}9.96 \\
9.98 \\
9.98\end{array}\right\}$ & 9.97 & $\begin{array}{r}30 \\
320\end{array}$ & 10 \\
\hline
\end{tabular}

* $\mathrm{KI}$ 原液濃度： $0.1000 \mathrm{~N}$

4. フェノール赤

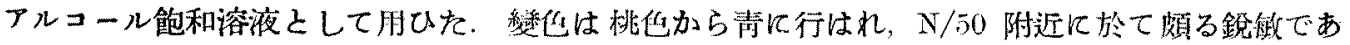
る.

\begin{tabular}{|c|c|c|c|c|}
\hline $\mathrm{KI}$ 溶液の濃度 (N) & 要したる N/10 & $\mathrm{AgNO}_{3}$ 楁液 & 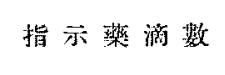 & $\mathrm{N} / 10 \mathrm{KOH}$ 醉数 \\
\hline $1 / 10 *$ & $\left.\begin{array}{l}10.33 \\
10.31 \\
10.33\end{array}\right\}$ & 10.32 & 2 & 2 \\
\hline $1 / 20$ & $\left.\begin{array}{l}10.33 \\
10.35 \\
10.33\end{array}\right\}$ & 10.34 & 2 & 2 \\
\hline $\begin{array}{r}1 / 50 \\
\end{array}$ & $\left.\begin{array}{l}10.36 \\
10.34 \\
10.34\end{array}\right\}$ & 10.35 & \}$_{5}^{4}$ & 3 \\
\hline $1 / 100$ & $\left.\begin{array}{l}10.36 \\
10.32 \\
10.31\end{array}\right\}$ & 10.34 & 7 & 4 \\
\hline
\end{tabular}

* KI 原液淑度： $0.1031 \mathrm{~N}$

5.コチニール゙

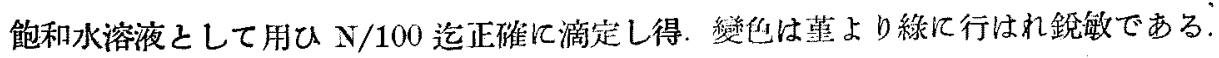




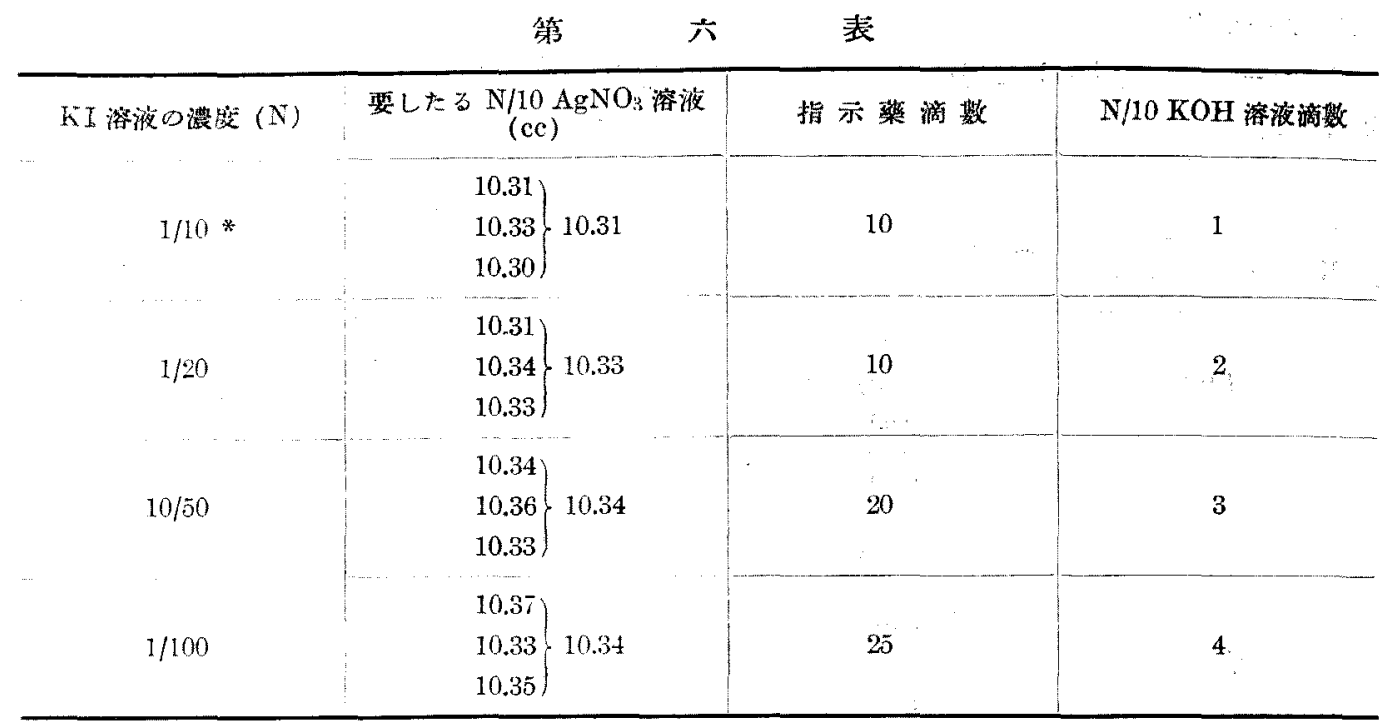

* $\mathrm{K} 1$ 原液壊度： $0.1031 \mathrm{~N}$

6. アゾリトミン

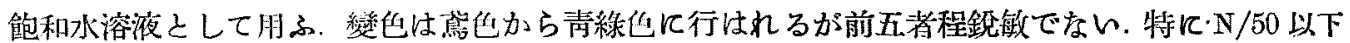
に於ては變色不明膫となる。既記の如くアルカリを州へぬ方が結果がよレやうである.

第 七 表

\begin{tabular}{|c|c|c|c|c|c|}
\hline $\begin{array}{l}\mathrm{KI} \text { 溶液の } \\
\text { 灙度 (N) }\end{array}$ & $\begin{array}{c}\text { 要したる } \mathrm{N} / 10 \mathrm{AgNO}_{3} \\
\text { 溶液 }(\mathrm{ec})\end{array}$ & 指示藥谪䌘 & $\begin{array}{l}\text { KI 溶液の } \\
\text { 濃度 }(\mathrm{N})\end{array}$ & $\begin{array}{c}\text { 要したるN } / 10 \mathrm{AgNO}_{3} \\
\text { 溶液 }(\mathrm{cc})\end{array}$ & 指示藥滴数 \\
\hline $1 / 10 *$ & $\left.\begin{array}{l}10.00 \\
10.02 \\
10.02\end{array}\right\} 10.01$ & 15 & $1 / 50$ & $\left.\begin{array}{l}10.02 \\
10.03 \\
10.01\end{array}\right\} 10.01$ & 25 \\
\hline $1 / 20$ & $\left.\begin{array}{l}10.03 \\
10.00 \\
10.00\end{array}\right\} 10.01$ & 80 & $1 / 100 * *$ & $\left.\begin{array}{l}10.04 \\
10.05\end{array}\right\} 10.045$ & 30 \\
\hline
\end{tabular}

* $\mathrm{KI}$ 原淮督便： $0.1000 \mathrm{~N}$

** 完丁點不明眽

撮 要

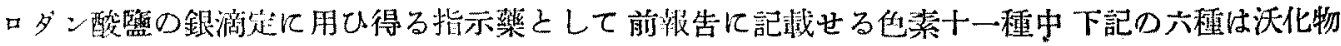
の銀滴定にも用ひ得ることを述べを.その中アジリトミンを除いては何れ多滿足すべき結果を與る.

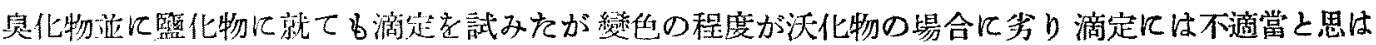
れる。

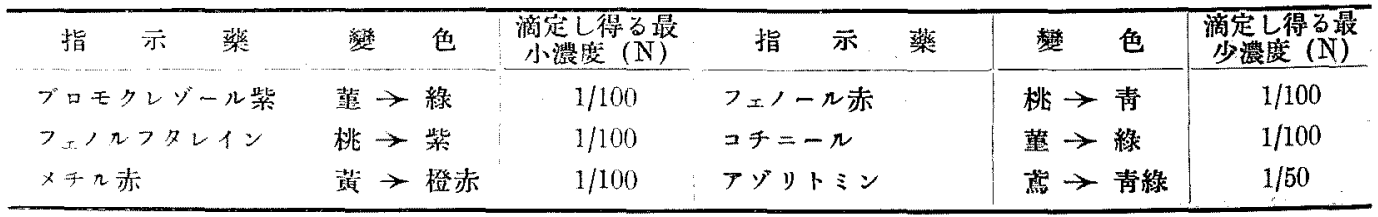

